\section{RECORD OF PACHYLOCERUS CRASSICORNIS (OLIVIER) (COLEOPTERA: CERAMBYCIDAE) FROM MAHARASHTRA}

\author{
A. Sen ${ }^{1}$, U. Hiremath ${ }^{2}$, R.D. Chaudhari ${ }^{2}$ and \\ H.V. Ghate ${ }^{3}$
}

${ }^{1,3}$ Department of Zoology, Modern College, Pune, Maharashtra 411005, India

${ }^{2}$ Shri Chhatrapati College, Junnar, Maharashtra 410502, India

Email: ${ }^{3}$ hemantghate@hotmail.com (corresponding author)

web supplement

Sen et al. (2005) recently reported presence of an interesting longicorn beetle, namely Pachylocerus corallinus Hope, belonging to the tribe Pyrestini (Cerambycidae: Cerambycinae) from Goa. Members of this longicorn beetle tribe are exclusively oriental and are characterized by red colouration.

While studying the beetle collection at Shri Chhatrapati College, Junnar, we identified another congeneric species, Pachylocerus crassicornis (Olivier), collected in Phaltan (near Nimbkar Agricultural Research Institute's farm, Satara district, Maharashtra; coll. U. Hiremath, date of collection August 1998, host plant unknown). Both these species are illustrated here (Image $1^{\mathrm{w}}$ ) and brief comments on differences between the two species are presented. The present species was identified on the basis of keys given by Gahan (1906). This may form the first record of this species from Maharashtra. Distribution records of Cerambycidae are poor largely due to problems in identifying these beetles.

P. crassicornis, female: length - 24mm; prothorax length - 5mm; prothorax breadth $-6 \mathrm{~mm}$; breadth at humerus $-7 \mathrm{~mm}$; elytra length $-16.5 \mathrm{~mm}$.

The present species resembles $P$. corallinus in most characters but the latter is somewhat smaller. The overall body colour is bright red with a pattern of black blotches, both on prothorax as well as elytra. Ventrally it is entirely black. All the body is covered with fine gray pubescence. Another difference from $P$. corallinus is that the setae on the distal part of $2^{\text {nd }}, 3^{\text {rd }}$ and $4^{\text {th }}$ antennomeres are relatively longer and stronger. Further, the legs in P. crassicornis are much darker and ventrally the femora are more blackish in the distal half.

The species $P$. crassicornis is known from southern India and Chota Nagpur as per Gahan (1906), but we have not come across any subsequent reports in literature. We hope that after publication of photographs (Image $1^{\mathrm{w}}$ ) of these two species of Pachylocerus, other naturalists may be able to identify this beetle and report its presence elsewhere.

Cerambycidae exhibit considerable size variation. Gahan (1906) gave size variation for P. crassicornis to be 17 to $25 \mathrm{~mm}$. Our

w see Image 1 in the web supplement at www.zoosprint.org

(C) Zoo Outreach Organisation; www.zoosprint.org Manuscript 1421; Received 16 August 2005; Finally accepted 09 December 2005; Date of publication 21 January 2006
REFERENCES

Gahan, C.J. (1906). Fauna of British India, Coleoptera Vol. I (Cerambycidae). Taylor and Francis, London, 329pp.

Sen, A., S. Rangnekar, P. Rangnekar and H.V. Ghate (2005). Record of Priotyrannus mordax (White) and Pachylocerus corallinus Hope (Coleoptera: Cerambycidae) from Goa. Zoos' Print Journal 20(5): 1869-1870.

\section{ACKNOWLEDGements}

The authors are grateful to the authorities of Junnar Taluka Shivner Shikshan Prasarak Mandal and Shri Chhatrapati College, Junnar for facilities to work on local insects. HVG and AS would like to thank the authorities of Modern College for facilities and encouragement.

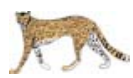

NOTE

ZOOS' PRINT JOURNAL 21(2): 2167-2169

\section{BIRDS OF THE GORGES OF VINDHYAS IN RAJASTHAN STATE}

\section{Satish Kumar Sharma ${ }^{1}$ and B.P. Singh ${ }^{2}$}

${ }^{1}$ Foundation For Ecological Security, 18, New Ahinsapuri, Fatehpura, Udaipur, Rajasthan 313001, India

${ }^{2}$ Foundation For Ecological Security, 12, Subhash Nagar Extn. East Alok Vidhyalaya Road, Bhilwara, Rajasthan 311001, India Email: ${ }^{1}$ fesudaipur@hotmail.com

Two main mountain ranges namely, the Aravallis and the Vindhyas are confined to the state of Rajasthan. The Vindhya range is situated towards the south-eastern part of the state. It is mainly confined to Bhilwara, Chittorgarh, Kota, Bundi, Sawai Madhopur, Karauli, Bharatpur and Dholpur districts of Rajasthan. The Vindhyan scrapland having an average elevation of 350-580m covers the area between Banas and Chambal rivers (Shetty \& Singh, 1987). Presence of gorges is a phenomenon of the Vindhya range. These gorges having rocky vertical banks are popularly known as $\mathrm{Nal}$ in local dialect. Generally they have waterfalls at places, which are picturesque during the monsoon period, but during summers most of them are dry. These gorges are part of characteristic drainage system of the Vindhyas. In the Aravallis, such gorges are absent and streams have flatish banks. The Chambal, Kali Sindh and Parwan are main perennial gorge rivers of the Vindhyan zone, while Menali, Mej, Berach, and Bharak are main seasonal gorge rivers of this zone.

The Vindhyas consist of flat-topped hills. It presents uniform view of ridge line when seen from a distance. Like Aravallis, it does not show peaks and saddles towards the ridgeline. Unlike Aravallis, it consists of reddish sheet rocks. Due to poor fragmentation in sheet rocks, percolation of rainwater is poor in the Vindhyas and the terrain is prone to heavy run-off. The soil layer is thin or absent on slopes and top of the Vindhyan

(C) Zoo Outreach Organisation; www.zoosprint.org Manuscript 1373; Received 06 June 2005; Revised received 17 November 2005; Finally accepted 10 December 2005; Date of publication 21 January 2006 
Table 1. List of common birds seen in the gorges of Vindhya range

\begin{tabular}{|c|c|c|c|c|c|c|c|c|}
\hline \multirow[t]{2}{*}{ S.No. } & \multirow[t]{2}{*}{ Species observed } & \multirow[b]{2}{*}{ Menal } & \multirow[b]{2}{*}{ Sitamata } & \multicolumn{3}{|c|}{ Name of gorge where observed } & \multirow[b]{2}{*}{ Chambal } & \multirow[b]{2}{*}{ Kalikhole } \\
\hline & & & & Kekadiya & Chenpuriyaa & Tehla & & \\
\hline 1. & Painted Spurfowl (Galloperdix lunulata) & & & & & & + & \\
\hline 2. & Indian Peafowl (Pavo cristatus) & & & + & & & & \\
\hline 3. & Black-rumped flameback (Dinopium benghalense) & + & & & & & + & \\
\hline 4. & Coppersmith Barbet (Megalaima haemacephala) & + & & & & & + & \\
\hline 5. & Indian Grey Hornbill (Ocyceros birostris) & + & & & & & + & \\
\hline 6. & Indian Roller (Coracias benghalensis) & & & + & + & & & \\
\hline 7. & White-throated Kingfisher (Halcyon smyrnensis) & + & + & + & + & & + & \\
\hline 8. & Green Bee-eater (Merops orientalis) & + & & + & & & + & \\
\hline 9. & Rose-ringed Parakeet (Psittacula krameri) & + & + & + & + & & + & + \\
\hline 10. & Plum-headed Parakeet (Psittacula cyanocephala) & + & + & & + & & + & \\
\hline 11. & Eurasian Eagle Owl (Bubo bubo) & + & + & + & + & & + & \\
\hline 12. & Rock Pigeon (Columba livia) & + & + & + & + & & + & + \\
\hline 13. & Laughing Dove (Streptopelia senegalensis) & & & + & + & + & + & \\
\hline 14. & Yellow-footed Green Pigeon (Treron phoenicoptera) & + & + & & & & + & \\
\hline 15. & Green Sandpiper (Tringa ochropus) & + & + & & & & + & \\
\hline 16. & Red-wattled Lapwing (Vanellus indicus) & + & & + & + & & + & \\
\hline 17. & River Tern (Sterna aurantia) & & & & & & + & \\
\hline 18. & Egyptian Vulture (Neophron percnopterus) & & & + & & & + & \\
\hline 19. & White-rumped Vulture (Gyps bengalensis) & + & & & & & + & \\
\hline 20. & Long-billed Vulture (Gyps indicus) & & + & + & & & + & \\
\hline 21. & Crested Serpent Eagle (Spilornis cheela) & + & & + & & & & \\
\hline 22. & Shikra (Accipiter badius) & + & & + & & & & \\
\hline 23. & Oriental Honey-buzzard (Pernis ptilorhynchus) & + & & & & & & \\
\hline 24. & Little Grebe (Tachybaptus ruficollis) & + & & & & & & \\
\hline 25. & Little Egret (Egretta garzetta) & + & & + & + & & & \\
\hline 26. & Intermediat Egret (Mesophoyx intermedia) & + & & & & & + & \\
\hline 27. & Cattle Egret (Bubulcus ibis ) & + & & + & & & + & \\
\hline 28. & Indian Pond Heron (Ardeola grayii) & + & & + & + & & + & \\
\hline 29. & Little Heron (Butorides striatus) & + & + & + & & & + & \\
\hline 29. & Grey Heron (Ardea cinerea) & & & & & & + & \\
\hline 30. & Darter (Anhinga melanogaster) & & & & & & + & \\
\hline 31. & Little Cormorant (Phalac rocorax niger) & & & & & & + & \\
\hline 32. & Wooly-necked Stork (Ciconia episcopus) & & & & & & + & \\
\hline 33. & Black Stork (Ciconia nigra) ${ }^{*}$ & & & & & & + & \\
\hline 34. & Indian Pitta (Pitta brachyura) & + & & & & & & \\
\hline 35. & Rufous Treepie (Dendrocitta vagabuda) & + & + & + & + & & & \\
\hline 36. & House Crow (Corvus splendens) & & & + & + & & & \\
\hline 37. & Small Minivet (Pericrocotus cinnamomeus) & + & & & & & & \\
\hline 38. & White-browed Fantail (Rhipidura aureola) & + & & + & & & & \\
\hline 39. & Black Drongo (Dicrurus macrocercus) & + & + & + & + & + & + & \\
\hline 40. & White-bellied Drongo (Dicrurus caerulescens) & + & + & + & & & + & \\
\hline 41. & Common Iora (Aegithina tiphia) & + & + & & & & + & \\
\hline 42. & Red-throated Flycatcher (Ficedula parva) & + & + & + & + & + & + & \\
\hline 43. & Tickell's Blue Flycatcher (Cyornis tickelliae) & + & & & & & & \\
\hline 44. & Grey-headed Canary Flycatcher (Culicicapa ceylonensis) & + & & & & & & \\
\hline 45. & Blue Rock Thrush (Monticola solitarius) & + & & & & & & \\
\hline 46. & Brown Rock-chat (Cercomela fusca) & + & & + & + & + & + & \\
\hline 47. & Common Myna (Acridotheres tristis) & + & & + & & & & \\
\hline 48. & Great Tit (Parus major) & + & + & & & & + & \\
\hline 49. & Dusky Crag Martin (Hirundo concolor) & + & & + & + & + & + & \\
\hline 50. & Red-rumped Swallow (Hirundo daurica) & + & & + & + & + & + & \\
\hline 51. & Wire-tailed Swallow (Hirundo smithii) & & & & + & & + & \\
\hline 52. & Barn Swallow (Hirundo rustica) & & & & & & + & \\
\hline 53. & Streak-throated Swallow (Hirundo flavicola) & & & & & & + & \\
\hline 54. & Red-vented Bulbul (Pycnonotus cafer) & + & & + & + & + & + & + \\
\hline 55. & Oriental White-eye (Zosterops palpebrosus) & + & + & & & & + & \\
\hline 56. & Large Grey Babbler (Turdoides malcomi) & & & + & + & & & \\
\hline 57. & Jungle Babbler (Turdoides striatus) & + & & & & & & \\
\hline 58. & Purple Sunbird (Nectarinia asiatica) & + & & & & & + & \\
\hline 59. & Yellow Wagtail (Motacilla flava) & + & & & & & + & \\
\hline 60. & Citrine Wagtail (Motacilla citreola) & + & + & + & & & + & \\
\hline & Total species present & 44 & 17 & 30 & 20 & 7 & 43 & 3 \\
\hline
\end{tabular}

+ - Non-breeding; + - Breeding

* Two birds were seen on upper most edge of one of the banks of Chambal river near Gardiya Mahadeo on Jan. 22, 2000. 
Table 2. Some ecological characteristics of the gorges of Vindhya range

\begin{tabular}{|c|c|c|c|}
\hline & Name of gorge & District & Remark \\
\hline 1. & Menal & Chittorgarh & $\begin{array}{l}\text { A "closed area" of Department of Forest. Seasonal stream and waterfall is present there. It is a part } \\
\text { of Menali river. Bank and bed have good vegetation cover. }\end{array}$ \\
\hline 2. & $\begin{array}{l}\text { Sitamata (Near Sitamata } \\
\text { Temple in Sitamata WS) }\end{array}$ & Chittorgarh & $\begin{array}{l}\text { Seasonal stream. High banks, covered with Ficus spp. Bed rocky and bouldery. Few spots have } \\
\text { surface water round the year. }\end{array}$ \\
\hline 3. & Kekadiya & Bhilwara & $\begin{array}{l}\text { Seasonal stream with high banks. Few spots have seepage and surface water round the year. } \\
\text { Bank and bed have poor vegetation cover. Chrysopogon fulvus commonly grows on banks during } \\
\text { rainy season. }\end{array}$ \\
\hline 4. & Chenpuriya & Bhilwara & $\begin{array}{l}\text { Seasonal stream with low banks. Few pits have water impounded round the year. Bank and bed } \\
\text { have poor vegetation cover. }\end{array}$ \\
\hline 5. & Tehla & Bhilwara & $\begin{array}{l}\text { Seasonal stream. Few spots have water round the year. Banks have moderately fair vegetation } \\
\text { cover. }\end{array}$ \\
\hline 6. & Chambal River & Kota & $\begin{array}{l}\text { Perennial river. Lower portion of both the banks are clad with good plant cover while upper part of } \\
\text { the banks are poor in vegetation. Three sites, namely Bhitariya Kund, Gardiya Mahadeo and } \\
\text { Gappar Nath were surveyed for listing the gorge birds. }\end{array}$ \\
\hline 7. & Kalikhole & Bhilwara & Seasonal stream. Few spots have water round the year. \\
\hline
\end{tabular}

hills. Due to so many reasons the Vindhyas are prone to dryness. Edaphic climax of Anogeissus pendula is seen on large parts of the area.

Very little is known about birds of the gorges of Vindhyas in Rajasthan. Some information about Chambal river gorges is available in literature (Rahmani \& Singh, 1996; Vyas, 2000). No information is available about birds of gorges of other Vindhyan districts of Rajasthan. To get a birds-eye view of avian fauna of the gorges of Vindhyas, the following sites were studied for five years from 1999 to 2004 (Table 1).

Vertical banks of gorges have rock crevices, cliffs, overhangs, holes, caves and concaves, which prove useful to many bird species. Sometimes riparian vegetation occur in wet and moist gorges and even arboreal species can be seen there. Seasonal gorges have some pits where water is available round the year. These pit are locally called darrah or dah, which are not only used as water holes by the wild animals, but also provide food to many bird species (Table 2).

It is evident that Menal and Chambal river gorges are richer in avian diversity than other gorges. These places are less disturbed than others. Chambal is a perennial river and availability of water is better in Menal than the rest of the gorges. These differences are probably responsible for the bird richness.

Rock Bee (Apis dorsata) hives are commonly seen in gorges. Many insectivorous birds, including Green Bee-eater are seen in the gorges. Mud nests of Dusky Crag Martin and Redrumped Swallows are seen under sheltered overhangs of rocks. Nests of Red-rumped Swallows can be seen up to $1.5 \mathrm{~m}$ deep on ceilings of the caves.

Presence of Long-billed Vultures was concluded by observing white marks of droppings near their roost and nest sites. Longbilled Vultures prefer wide gorges as well as abrupt vertical rise in hills for roosting and nesting. In narrow gorges, smooth flight movements are not possible. When a narrow gorge is patronized, area near the upper edge of the bank is selected for nesting and roosting. While studying in Chambal area, it was noticed that chicks of Long-billed Vulture while present on cliff nest, generally keep their heads towards hill sides. Some birds like Bubo bubo, Neophron percnopterus, Gyps indicus, Cercomela fusca, Hirundo spp., and Monticola solitarious can be termed as true gorge birds which are generally seen in most of the gorges. Many birds like Ashy Crown Sparrow Lark (Eremopterix grisea) and Chestnut-bellied Sandgrouse (Pterocles exustus) can be seen out of gorges in flattish-barren and bouldar zone in the Vindhyas.

\section{REFERENCES}

Rahmani, A.R. and B. Singh (1996). White-necked or Woolly-necked Strok Ciconia episcopus (Boddaert) nesting on cliffs. Journal of the Bombay Natural History Society 93(2): 293-294.

Shetty, B.V. and V. Singh (1987). Flora of Rajasthan. Vol. I. Botanical Survey of India, Calcutta.

Vyas, R. (2000). Distribution of Painted Spurfowl Galloperdix lunulata in Rajasthan. MOR (Newsletter of the World Pheasent Association) 2: 2.

\section{ACKNOWLEDGEMENTS}

Authors are very grateful to Sh. Jagdeesh Rao, Sh. Sanjay Joshi, Sh. Rajesh Tete, Sh. Shantanu Sinha Roy, Ms. Shruti Sinha, Sh. B.K. Sharma, Sh. Bishwaroop Thakur and Sh. Ramswaroop Lakhara for help and facilities. First author is very thankful to Sh. Rakesh Vyas, Sh. K.C. Joshi, Sh. Ravindra Singh Tomar, Sh. A.H. Jaidi, Sh. Dhruv Kumar, Sh. Anil Kumar and other members of Hodoti Naturalists Society, Kota, for providing motor boat to study birds of Chambal river.

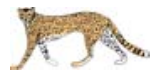

